\title{
Structural markers of the evolution of whey protein isolate powder during aging and effects on foaming properties
}

\author{
E.-A. Norwood, ${ }^{*} \dagger$ C. Le Floch-Fouéré, $\dagger^{1}$ V. Briard-Bion, $\dagger$ P. Schuck, $\dagger$ T. Croguennec, $\dagger$ and R. Jeantet $\dagger$ \\ ${ }^{*}$ Centre National Interprofessionnel de l'Economie Laitière (CNIEL), 42, rue de Châteaudun 75314 Paris, France \\ †Science et Technologie du Lait et de l'Oeuf (STLO), Agrocampus Ouest, INRA, 35000, Rennes, France
}

\begin{abstract}
The market for dairy powders, including high addedvalue products (e.g., infant formulas, protein isolates) has increased continuously over the past decade. However, the processing and storage of whey protein isolate (WPI) powders can result in changes in their structural and functional properties. It is therefore of great importance to understand the mechanisms and to identify the structural markers involved in the aging of WPI powders to control their end use properties. This study was performed to determine the effects of different storage conditions on protein lactosylations, protein denaturation in WPI, and in parallel on their foaming and interfacial properties. Six storage conditions involving different temperatures $(\theta)$ and water activities $\left(\mathrm{a}_{\mathrm{w}}\right)$ were studied for periods of up to 12 mo. The results showed that for $\theta \leq 20^{\circ} \mathrm{C}$, foaming properties of powders did not significantly differ from nonaged whey protein isolates (reference), regardless of the $a_{w}$. On the other hand, powders presented significant levels of denaturation/aggregation and protein modification involving first protein lactosylation and then degradation of Maillard reaction products, resulting in a higher browning index compared with the reference, starting from the early stage of storage at $60^{\circ} \mathrm{C}$. These changes resulted in a higher foam density and a slightly better foam stability (whisking) at $6 \mathrm{mo}$. At $40^{\circ} \mathrm{C}$, powders showed transitional evolution. The findings of this study will make it possible to define maximum storage durations and to recommend optimal storage conditions in accordance with WPI powder end-use properties.
\end{abstract}

Key words: whey protein, storage, lactosylation, denaturation, foam

Received December 21, 2015.

Accepted March 24, 2016.

${ }^{1}$ Corresponding author: cecile.lefloch-fouere@agrocampus-ouest.fr

\section{INTRODUCTION}

Milk and by-products are increasingly dried these days to extend their stabilization to up to $3 \mathrm{yr}$ due to the lowering of water activity $\left(\mathbf{a}_{\mathrm{w}}\right)$, and to reduce product volume by a factor of 5 to 15 to reduce both storage facility needs and transport costs. Powder processing represents a significant global market share with 10 million tons of milk powder produced per year on a global scale, corresponding to $20 \%$ of world milk production. High protein powders with targeted functionalities have been developed in the past decades, including whey protein concentrates (WPC) and isolates (WPI) that have generated increased interest.

Whey protein isolate consists of $>90 \%$ protein $(\mathrm{Bu}-$ rin et al., 2000), with about $70 \% \beta$-LG and $20 \% \alpha-\mathrm{LA}$ (McClements et al., 1993). Whey proteins in their native state have biological and functional properties that appear to have undeniable advantages in many food applications. They are recognized for their nutritional role, solubility, and ability to form gels, emulsions, and foams. Whey proteins form viscoelastic layers at the air/water interface when they are adsorbed, which can lead to a resistant and cohesive interfacial network under certain conditions, improving foam stability (Martin et al., 2002). Their surface activity properties allow the formation of a wide range of foamed products such as bread, meringues, and ice creams. In fact, proteins are often used as foaming agents in food because they contribute both to foam formation and foam stability, and controlling these properties is therefore of great interest for the food industry.

However, dairy powders can be subjected to extremely variable conditions during the period of preservation (storage, export). Leinberger (2006) showed that $40 \%$ of shipments were subjected to temperatures above $45^{\circ} \mathrm{C}$, sometimes reaching $57^{\circ} \mathrm{C}$ inside the most exposed containers during continental or inter-continental delivery over periods of up to 3 mo. As a result, studies have shown that these WPI powders evolve during storage from a functional point of view, thereby affecting their commercial value (Anema et al., 2006; Gaiani et al., 
2006; Havea, 2006). It is therefore of utmost importance to characterize these changes and link them to structural modifications to identify markers of change for early detection and to recommend a range of conditions to ensure their end-use properties.

In this study, 2 WPI powders were produced from a fresh whey protein ultra-diafiltrate to achieve $a_{w}$ close to industrial storage conditions or as a result of a poor control of the drying parameters $(0.23$ and 0.36 , respectively). These powders were stored at temperatures representative of storage conditions [i.e., from $4^{\circ} \mathrm{C}$ (reference) to $60^{\circ} \mathrm{C}$ ]. Then the change of protein structures was followed in the powder state for periods of up to 12 mo and the foaming properties after powder rehydration.

\section{MATERIALS AND METHODS}

\section{WPI Powders}

The WPI powders were obtained by spray drying of a whey protein ultra-diafiltrate obtained from the ultrafiltration and diafiltration of milk microfiltrate. This whey protein ultra-diafiltrate contained $27.8 \%$ DM (wt/wt) including approximately $90 \%$ milk proteins. The spray drying was carried out at a constant flow rate of around $100 \mathrm{~L} \cdot \mathrm{h}^{-1}$, and the inlet and outlet temperatures were fixed at 169 and $66^{\circ} \mathrm{C}$, respectively, to obtain a powder $\mathrm{a}_{\mathrm{w}}$ of 0.23 , and at 146 and $54.3^{\circ} \mathrm{C}$ to obtain a powder $\mathrm{a}_{\mathrm{w}}$ of 0.36 . After drying, WPI powders presented water content of 7.5 and $10.1 \%$ at $\mathrm{a}_{\mathrm{w}}$ of 0.23 and 0.36 , respectively. Both were packed under air in 400-g airtight tins.

\section{Storage of WPI Powders}

The WPI powder tins were stored in chambers heated at $4,20,40$, and $60^{\circ} \mathrm{C}$ for periods of up to $12 \mathrm{mo}$. One tin per temperature and $\mathrm{a}_{\mathrm{w}}$ condition was brought out after $0.5,1,3,6,9$, and 12 mo of storage to analyze the structural and functional properties of the powders.

\section{Powder Composition}

The native forms of $\beta$-LG and $\alpha$-LA were quantified in stored powders by reverse-phase chromatography after precipitation at $\mathrm{pH} 4.6$ using a 300A $8 \mu M 150$ $\times 2.1$ MM PLRP-S column (Polymer Laboratories, Amherst, MA). The latter was connected to a HPLC made of a separation system Waters 2695, a double wavelength detector Waters 2487 and an acquisition and Empower data processing software (Milford, MA). The elution flow was $0.2 \mathrm{~mL} \cdot \mathrm{min}^{-1}$ using a gradient of acetonitrile obtained by an appropriate combination of buffer solution A (trifluoroacetic acid, TFA, 0.1\%) and buffer solution B ( $80 \%$ acetonitrile and $0.1 \%$ TFA). The column was first equilibrated with $35 \%$ buffer solution $\mathrm{B}$ and then linear gradients of buffer solution B moving from 35 to $44 \%$ in $3 \mathrm{~min}$, from 44 to $48 \%$ in 11 min, from 48 to $53 \%$ in $12 \mathrm{~min}$, and finally from 53 to $62 \%$ in 14 min were used to elute the proteins. Proteins were detected at $214 \mathrm{~nm}$.

\section{Quantification of Free Thiol Groups}

The thiol groups exposed on the protein surface were quantified using Ellman's method (Ellman, 1959). Briefly, $100 \mu \mathrm{L}$ of a $10 \mathrm{~g} \cdot \mathrm{L}^{-1}$ solution of rehydrated stored WPI powder were mixed with $900 \mu \mathrm{L}$ of Tris glycine buffer $(50 \mathrm{mM}, \mathrm{pH} 7.0)$ and $25 \mu \mathrm{L}$ of a $2,2^{\prime}$-dinitro-5,5dithiodibenzoate solution (8 $\mathrm{m} M$; DTNB, Merck, Darmstadt, Germany). After $2 \mathrm{~h}$ at room temperature, absorbance was measured at $412 \mathrm{~nm}$ and the accessible DTNB thiol groups were determined according to $\varepsilon_{412 \mathrm{~nm}}$ $=13,600 M^{-1} \cdot \mathrm{cm}^{-1}$.

\section{Level of $\beta-L G$ Lactosylation}

The percentages of lactosylated $\beta-\mathrm{LG}$ were determined by mass spectrometry after protein separation on reverse-phase HPLC using a $\mathrm{C} 4$ Vydac column (214TP5215, $150 \times 2.1 \mathrm{~mm}$; Grace, Columbia, MD). The analysis was carried out with $15 \mu \mathrm{L}$ of a $0.5 \%$ (wt/ wt) solution reconstituted in milliQ water $2 / 3$ diluted with a $0.212 \%$ buffer solution of TFA. The flow applied was $0.25 \mathrm{~mL} \cdot \mathrm{min}^{-1}$ with an acetonitrile gradient. At the end of the column, a fraction of the eluate entered a QSTAR XL mass spectrometer (MDS Sciex, Toronto, Ontario, Canada) at a flow rate of $75 \mu \mathrm{L} \cdot \mathrm{min}^{-1}$. Proteins were ionized with an ion sprayer source before determining their mass with a TOF scanner (MDS Sciex) previously calibrated with $\beta$-CN peptide from $\beta$-casein $\mathrm{f}(193-209)$. The mass acquisition was carried out in the mass range of $m / z 500$ to 3,000 at $5 \mathrm{kV}$.

The percentage of lactosylation was determined using the following calculation:

$$
\frac{\mathrm{I}(\text { lact })}{\mathrm{I}(\mathrm{NP})+\mathrm{I}(\text { lact })} \times \% \mathrm{NP}
$$

where I(lact) is the intensity of the lactosylated protein, I(NP) is the intensity of the native protein, and $\% \mathrm{NP}$ is the $\%$ native protein amount determined from reverse-phase HPLC. 


\section{Functional Analysis of WPI Powders}

The browning index (BI) of powders was determined by measuring $\mathrm{L}^{*} \mathrm{a} \mathrm{b}^{*}$ parameters (Konica Minolta Photo Imaging France SAS, Roissy, France) using the formula (Maskan, 2001):

$$
\mathrm{BI}=\frac{[100(x-0.31)]}{0.17}
$$

with

$$
x=\frac{(a+1.75 L)}{(5.645 L+a-3.012 b)} .
$$

Foaming properties were evaluated by beating $200 \mathrm{~mL}$ of $50 \mathrm{~g} \cdot \mathrm{L}^{-1}$ of WPI solution at room temperature with a Hobart N50 whisk (Hobart, Peterborough, UK) at speed 3 (maximal speed) for 2 min. A foam core of $74 \mathrm{~cm}^{3}$ was removed and the initial foam weight was determined (time $t_{i}$ ). The foam core was placed in a glass funnel on a measuring tube previously tared and the exuded liquid was regularly measured for up to 60 min. The foam stability (FS; \%) was calculated during drainage according to Howell and Taylor (1995):

$$
\mathrm{FS}=\frac{\text { Initial foam weight }\left(t_{i}\right)-\text { drained weight }(t)}{\text { Initial foam weight }\left(t_{i}\right)} \times 100 \text {. }
$$

The foam density $\left(\mathrm{FD} ; \mathrm{g} \cdot \mathrm{cm}^{-3}\right)$ was evaluated according to

$$
\mathrm{FD}=\frac{\text { Foam weight }(\mathrm{g})}{\text { Foam volume }\left(\mathrm{cm}^{3}\right)}
$$

\section{RESULTS AND DISCUSSION}

\section{Properties in the Dry State}

Fresh Powder Composition. Fresh WPI powders $\left(t_{0}\right)$ of $\mathrm{a}_{\mathrm{w}} 0.23$ and 0.36 were characterized by 4.7 and $16.2 \%$ proteins, respectively, that precipitated at $\mathrm{pH}$ 4.6. These were considered to be proteins that had denatured during spray drying or prior processing steps. Because this study deals with the structural and functional evolution of proteins during storage, their contribution does not appear in the present results. Moreover, no structural or functional modifications were detected during $9 \mathrm{mo}$ storage at $4^{\circ} \mathrm{C}$ (data not shown). The powder stored at $4^{\circ} \mathrm{C}$ was therefore taken as a reference (Ref) and any difference from Ref properties were considered as structural or functional or both changes affected by storage conditions.

Protein Lactosylation and Denaturation of Stored Powders. In agreement with Stapelfeldt et al. (1997), the kinetics of powder property modifications were slightly faster at $\mathrm{a}_{\mathrm{w}} 0.36$ than those at $\mathrm{a}_{\mathrm{w}} 0.23$. In their native state, $\alpha-\mathrm{LA}$ and $\beta-\mathrm{LG}$ are soluble at $\mathrm{pH} 4.6$, and in reverse-phase HPLC are eluted with a retention time of $20 \mathrm{~min}$ and 33 to $34 \mathrm{~min}$, respectively (double peak corresponding to the $2 \beta$-LG variants), with the gradients used in this study (Figure 1a). Any reduction in the area of the native form peaks or any modification of their elution time are ways to obtain the nonnative proteins that are considered to be the denatured/aggregated or the lactosylated fractions (or both) of $\alpha$-LA and $\beta$-LG during storage.

The denatured/aggregated proteins were quantified by the difference with Ref in reverse-phase chromatography after precipitation at $\mathrm{pH}$ 4.6. Powders stored at $20^{\circ} \mathrm{C}$ were stable for 6 mo and showed only small changes after 12 mo (Figure 1a and 1b), corresponding to 7\% denatured $\beta$-LG for a powder of $a_{w} 0.23$. A similar level of denaturation was observed for powders stored at $40^{\circ} \mathrm{C}$ for $15 \mathrm{~d}$. After $12 \mathrm{mo}$ of storage at $40^{\circ} \mathrm{C}$, powders of $\mathrm{a}_{\mathrm{w}} 0.23$ and 0.36 presented $\sim 33 \%$ and more than $42 \%$ denatured proteins, respectively. A fraction of these had a delayed elution time, supposing the denatured proteins to be more hydrophobic (Gulzar et al., 2013). A part of the nonaggregated proteins were lactosylated. The fraction of lactosylated proteins (\%; Figure 1b) that could carry one or more lactose per protein was less than $10 \%$ of whey proteins at $t_{0}$. This proportion regularly increased to reach $21 \%\left(\mathrm{a}_{\mathrm{w}} 0.23\right)$ and $24 \%\left(\mathrm{a}_{\mathrm{w}}\right.$ 0.36 ) after $12 \mathrm{mo}$ of storage at $20^{\circ} \mathrm{C}$. The lactosylation phenomenon evolved faster in powders stored at 40 and $60^{\circ} \mathrm{C}$. At $40^{\circ} \mathrm{C}$, the level of lactosylated proteins reached $30 \%$ after $15 \mathrm{~d}$ of storage, then remained stable for up to $3 \mathrm{mo}$ of storage before decreasing. The protein structure is changed in view of its lactosylation state without any change in its secondary structure, which was analyzed by circular dichroism (data not shown). Protein lactosylation constitutes therefore a marker of early change in the powder during storage. Lactosylation was rapidly undetectable in powders stored at $60^{\circ} \mathrm{C}$. Indeed, over the first weeks of storage at $60^{\circ} \mathrm{C}$, it was actually possible to quantify protein lactosylation; however, lactosylated proteins remained detectable but no longer quantifiable for longer storage time as a result of the growing complexity of the signal. The decrease in proportion of lactosylated protein after 3 mo of storage at $40^{\circ} \mathrm{C}$ and the rapidly undetectable lactosylation signal at $60^{\circ} \mathrm{C}$ corresponded to a high level of progres- 
sion of denaturation (Figure 1b). This is in accordance with Norwood et al. (2016) suggesting that, with storage time, lactosylated proteins are getting through the

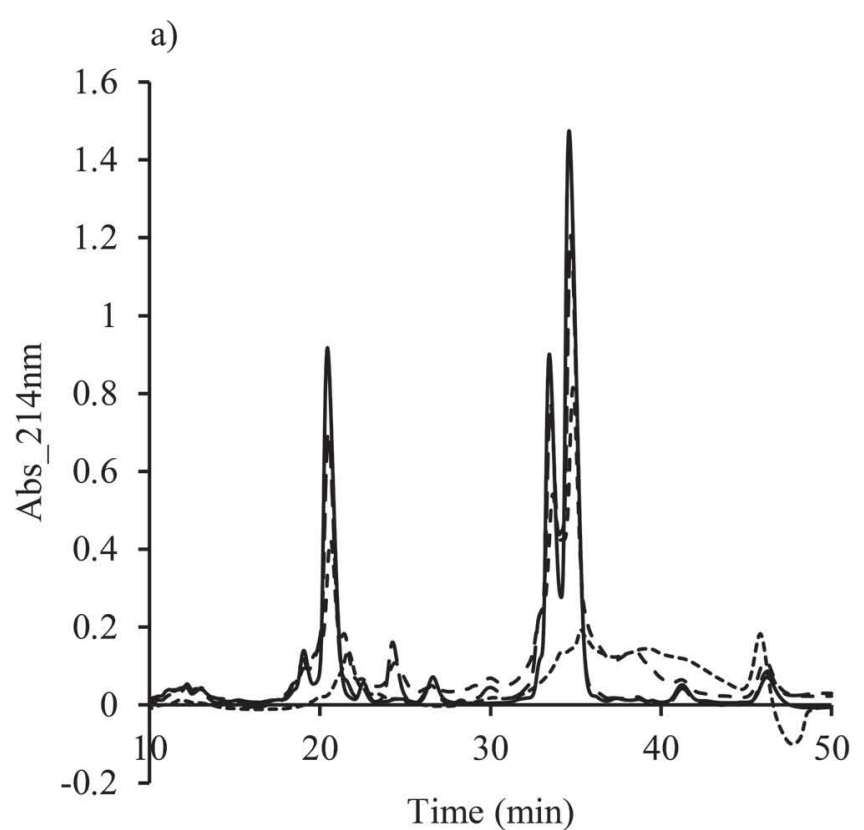

b)

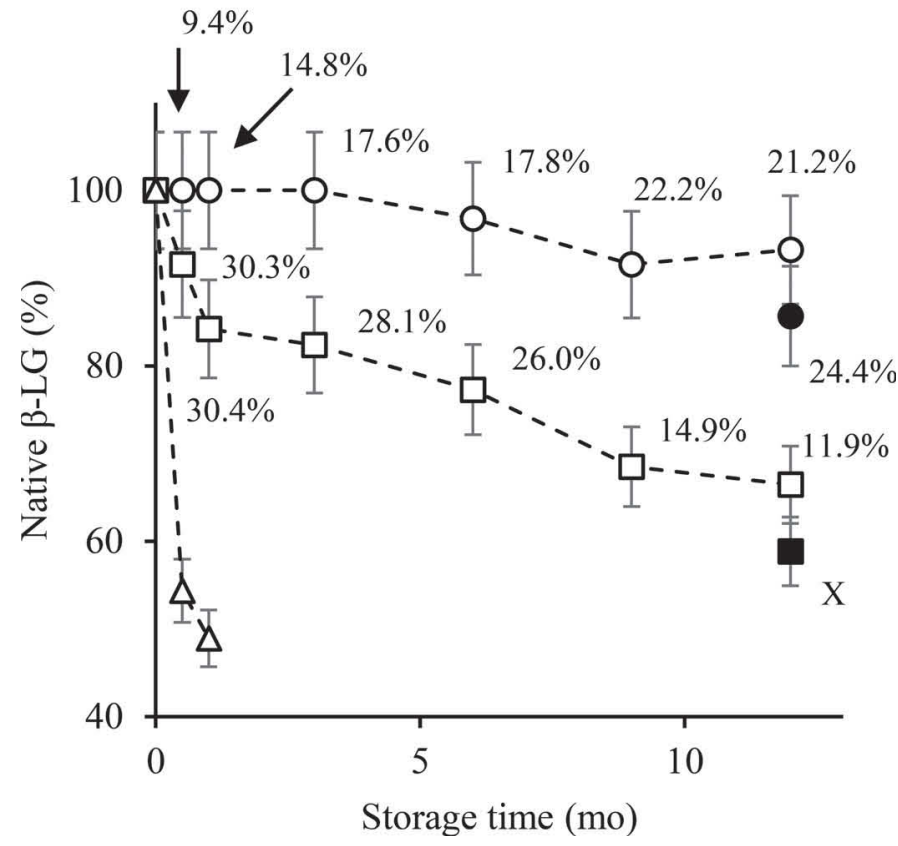

Figure 1. (a) Reverse-phase profile of whey protein isolate powders of water activity $\left(\mathrm{a}_{\mathrm{w}}\right) 0.23$ at $t_{0}$ (solid line) and stored for 12 mo at $20^{\circ} \mathrm{C}$ (long-dashed line) and at $40^{\circ} \mathrm{C}$ (dashed line), and stored for $6 \mathrm{mo}$ at $60^{\circ} \mathrm{C}$ (dotted line). (b) Influence of storage time and temperature on the amount of native $\beta-\mathrm{LG}$ at $\mathrm{pH} 4.6$ during storage of powder of $\mathrm{a}_{\mathrm{w}} 0.23$ at $20^{\circ} \mathrm{C}$ (circle), $40^{\circ} \mathrm{C}$ (square), and $60^{\circ} \mathrm{C}$ (triangle). Powders of $\mathrm{a}_{\mathrm{w}} 0.36$ stored for $12 \mathrm{mo}$ at $20^{\circ} \mathrm{C}$ (solid circle) and $40^{\circ} \mathrm{C}$ (solid square). Percentage of lactosylation is indicated beside the corresponding sample with relative error, measured on control, below $5.3 \%$.

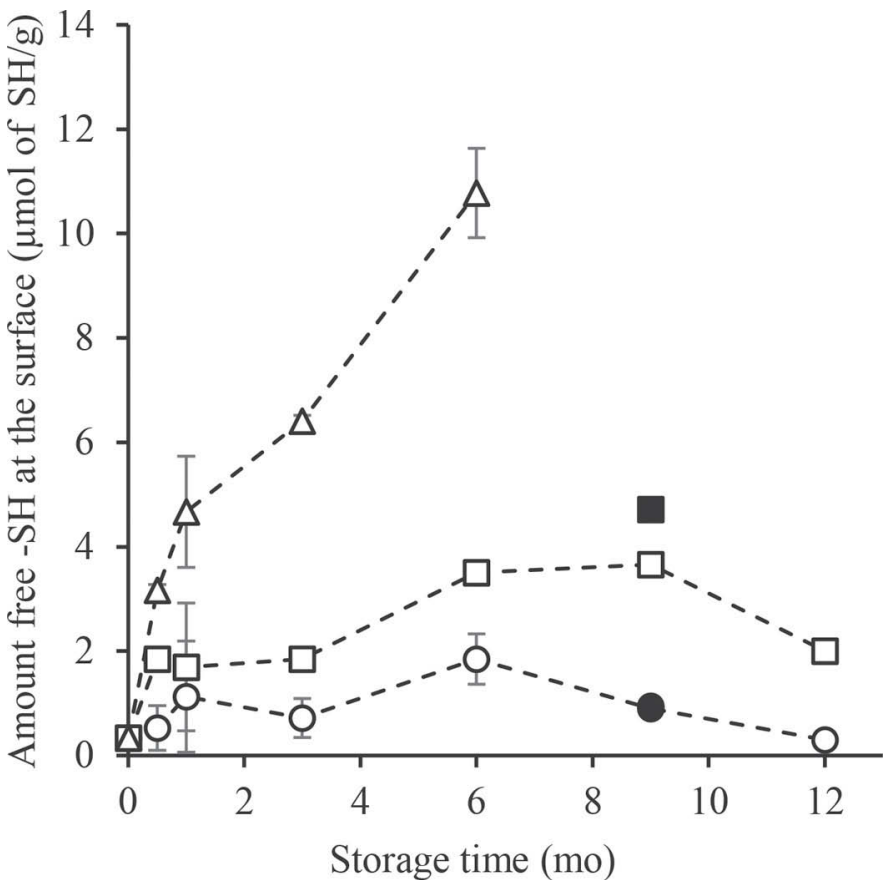

Figure 2. Influence of storage time on the amount of free thiol groups at the protein surface. Powders of water activity $\left(\mathrm{a}_{\mathrm{w}}\right) 0.23$ stored at $20^{\circ} \mathrm{C}$ (open circle), at $40^{\circ} \mathrm{C}$ (open square) and at $60^{\circ} \mathrm{C}$ (open triangle). Powders of $\mathrm{a}_{\mathrm{w}} 0.36$ stored $9 \mathrm{mo}$ at $20^{\circ} \mathrm{C}$ (solid circle), at $40^{\circ} \mathrm{C}$ (solid square). Standard deviation $<1.2 \mu \mathrm{mol}$ of $\mathrm{SH} / \mathrm{g}$.

process of the Maillard reaction, which ends up with the formation of aggregates in the dry state.

Changes in protein conformation were monitored by quantification of free thiol groups accessible to the DTNB probe (Figure 2). At $t_{0}$, the level of free thiol groups was $0.34 \pm 0.016 \mu \mathrm{mol}-\mathrm{SH} / \mathrm{g}$ of protein. Among the whey proteins, only $\beta-\mathrm{LG}$ and BSA have a free thiol group. It is possible to consider the concentration of BSA to be negligible compared with that of $\beta$-LG. On this basis, it can be estimated that only $1 \%$ of $\beta$-LG presented a free thiol group at $t_{0}$, in agreement with the structural data indicating that the free thiol group of $\beta$-LG (Cys121) is buried in the protein structure (Sawyer et al., 1999).

Exposure of free thiol groups increased during storage, reflecting an opening in protein structure (denaturation). For powders stored at $20^{\circ} \mathrm{C}$ for $12 \mathrm{mo}$, the amount of free thiol was not significantly different from the Ref. At $40^{\circ} \mathrm{C}$ and after 9 mo of storage, the levels of free thiol were $3.66 \pm 0.11$ and $4.71 \pm 0.05 \mu \mathrm{mol}$ $-\mathrm{SH} / \mathrm{g}$ of protein for powders with $\mathrm{a}_{\mathrm{w}} 0.23$ and 0.36 , respectively. This level corresponded to $10 \%\left(\mathrm{a}_{\mathrm{w}} 0.23\right)$ and $13 \%\left(a_{w} 0.36\right)$ of $\beta-L G$ that had a free thiol group accessible to the probe. A decrease was observed at approximately 12 mo of storage. In agreement with the previously reported changes in the denaturation level, 


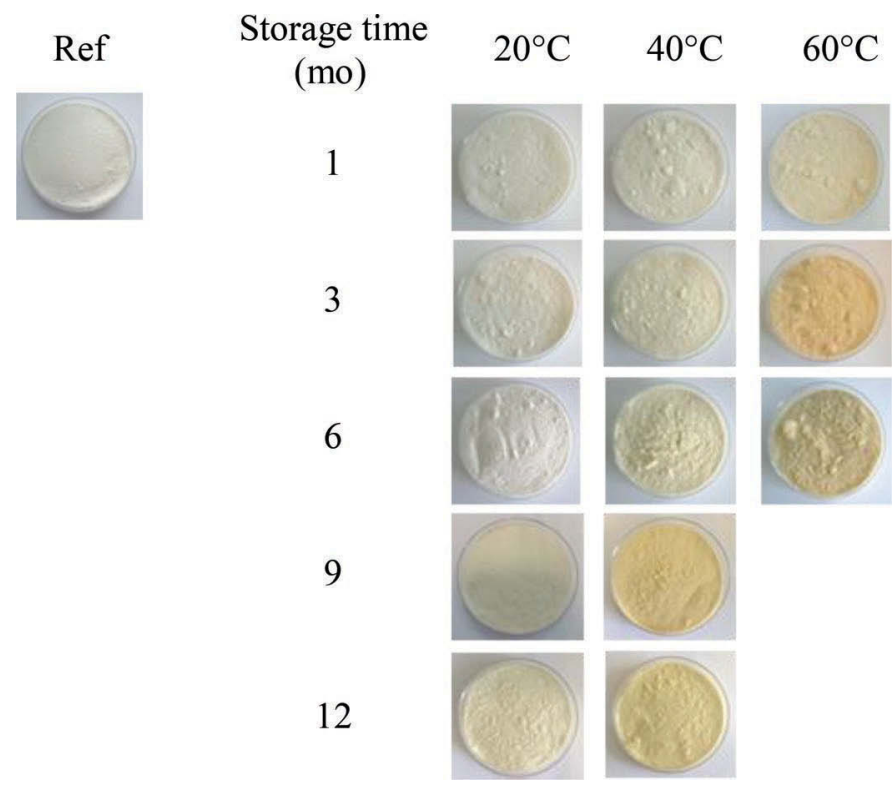

Figure 3. Effect of storage time and temperature on powder color. Ref $=$ reference. Color version available online.

this free thiol exposure might participate in exchange reactions with other protein disulfide bonds (Roefs and De Kruif, 1994; Hoffmann and van Mil, 1997; Visschers and de Jongh, 2005).

Color of Stored Powders. The color of dairy powders constitutes an essential criterion for their end use properties and reflects overall changes occurring in powders because of the Maillard reaction, which is one of the major deteriorative factors during storage of dehydrated dairy products. Indeed, dairy powders that incorporate amorphous lactose are susceptible to nonenzymatic browning through the Maillard reaction. The color development was therefore observed (Figure 3) and analyzed through the change of the browning index (Table 1).

Table 1. Effect of storage time and temperature on browning index of powders of water activity $\left(\mathrm{a}_{\mathrm{w}}\right) 0.23$ stored at 20,40 , and $60^{\circ} \mathrm{C}$ and powders of $\mathrm{a}_{\mathrm{w}} 0.36$ stored for $12 \mathrm{mo}$ at 20 and $40^{\circ} \mathrm{C}(\mathrm{SD}<0.26)$

\begin{tabular}{|c|c|c|c|}
\hline \multirow{2}{*}{$\begin{array}{l}\text { Storage } \\
\text { time (mo) }\end{array}$} & \multicolumn{3}{|c|}{$\mathrm{a}_{\mathrm{w}} 0.23$} \\
\hline & $20^{\circ} \mathrm{C}$ & $40^{\circ} \mathrm{C}$ & $60^{\circ} \mathrm{C}$ \\
\hline$t_{0}$ & $14.99 \pm 0.02$ & $14.99 \pm 0.02$ & $14.99 \pm 0.02$ \\
\hline 0.5 & $15.19 \pm 0.01$ & $17.61 \pm 0.03$ & $51.69 \pm 0.06$ \\
\hline 1 & $15.14 \pm 0.03$ & $20.57 \pm 0.04$ & $53.44 \pm 0.09$ \\
\hline 3 & $15.37 \pm 0.01$ & $26.21 \pm 0.02$ & $68.23 \pm 0.26$ \\
\hline 6 & $15.99 \pm 0.06$ & $35.69 \pm 0.14$ & $72.53 \pm 0.11$ \\
\hline 9 & $16.52 \pm 0.03$ & $41.80 \pm 0.04$ & $\mathrm{ND}^{1}$ \\
\hline 12 & $17.09 \pm 0.12$ & $37.94 \pm 0.05$ & ND \\
\hline & $18.95 \pm 0.03^{2}$ & $52.08 \pm 0.06^{2}$ & \\
\hline
\end{tabular}

${ }^{1} \mathrm{ND}=$ not determined.

${ }^{2}$ Results for powders of $\mathrm{a}_{\mathrm{w}} 0.36$.
Powders developed color changes with storage time and temperature (Figure 3). The lowest browning index value (15) was found for the nonaged powder and the highest (72.5) for powders stored for 6 mo at $60^{\circ} \mathrm{C}$; Indeed, WPI powders stored at $60^{\circ} \mathrm{C}$ appeared to be yellower from the first days of storage (Table 1). Powders stored at $20^{\circ} \mathrm{C}$ showed a slight change in the browning index in accordance with the relatively small changes in protein lactosylation. At $40^{\circ} \mathrm{C}$, powders browned to an intermediate level, BI values being in the 17.6 to 41.8 range. Several studies have reported powder color changes with storage time and temperature $\left(\geq 50^{\circ} \mathrm{C}\right)$, suggesting participation of the Maillard reaction (Stapelfeldt et al., 1997; Burin et al., 2000; Martinez-Alvarenga et al., 2014). The Maillard reaction is based on the condensation of amino groups on reducing sugars, then followed by degradation of the condensation products and the formation of brown compounds. Due to diafiltration of the ultrafiltrate before spray drying, WPI powders consist of about $90 \%$ protein and a negligible amount of lactose. However, a very small amount of lactose still remains in an amorphous state in the powder product $(\sim 1.2 \% \mathrm{wt} / \mathrm{wt}$ corresponding to a lactose/protein molar ratio of 0.7 ) of which part is associated with proteins, as indicated by mass spectrometry analysis. Moreover, it is interesting to note that the level of lactosylation first increased for storage at $40^{\circ} \mathrm{C}$ up to 3 mo when maximum lactosylation was reached with no change in the browning index. At this point, the latter started to increase continuously, whereas the level of lactosylation decreased concomitantly and tended to be undetectable after 12 mo of storage. It can be hypothesized that proteins were extensively modified by lactosylation after 3 mo of storage at $40^{\circ} \mathrm{C}$, increasing the rate of the subsequent Maillard reaction and leading to the formation of new colored compounds. These results are consistent with the studies of Guyomarc'h et al. (2000) and Le et al. (2013), the first of which reported that protein powders stored for 3.5 wk at $52^{\circ} \mathrm{C}$ exhibited a brown color and the latter that incubation at $90^{\circ} \mathrm{C}$ for $2,6,12$, and 24 $\mathrm{h}$ led to an increase in the amount of protein crosslinking as an extent of Maillard reactions. Other studies reported that sugar binding to $\beta-\mathrm{LG}$ in the dry state seemed to provoke protein aggregation (Medrano et al., 2009; Norwood et al., 2016). Moreover, the higher the $\mathrm{a}_{\mathrm{w}}$ tested in this study, the higher the browning index became (Table 1), in accordance with the results of Stapelfeldt et al. (1997). Aggregation from crosslinking might also be due to heat-induced denaturation of proteins in view of the increase in free thiol groups exposed on the protein surface. In such a scheme, the storage temperature would act as a dry heat treatment, which could affect the exposure of buried thiol groups 


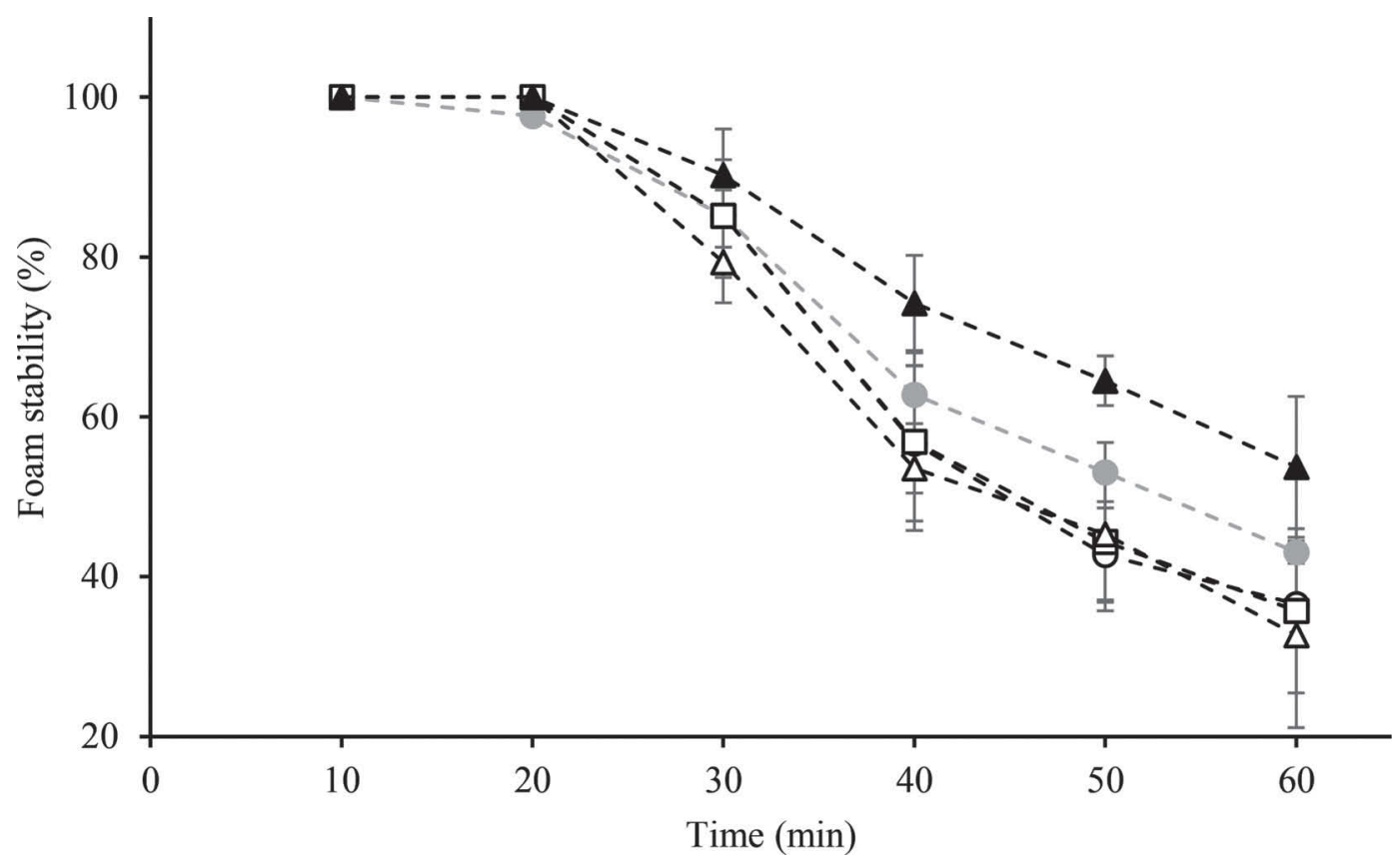

Figure 4. Effect of storage time and temperature on foam stability. Powders of water activity $\left(\mathrm{a}_{\mathrm{w}}\right) 0.23$ at $t_{0}$ (solid gray circle) and stored 12 mo at $20^{\circ} \mathrm{C}$ (open circle), at $40^{\circ} \mathrm{C}$ (open square) and 6 mo at $60^{\circ} \mathrm{C}$ (open triangle). Powder of $\mathrm{a}_{\mathrm{w}} 0.36$ stored 6 mo at $60^{\circ} \mathrm{C}$ (solid black triangle). Standard deviation $<11.5 \%$.

with partial unfolding of $\beta$-LG, which initiates thiol or disulfide interchange reactions leading to protein aggregation (Hoffmann and van Mil, 1997; Busti et al., 2006).

\section{Functional Properties After Reconstitution}

Foaming Properties. Foams are thermodynamically unstable systems due to drainage of the aqueous phase surrounding air bubbles. This criterion was assessed over time through the change of FS (Figure 4) and FD (Figure 5). Only the results obtained after 12 mo of storage at $\theta \leq 40^{\circ} \mathrm{C}$ and 6 mo at $60^{\circ} \mathrm{C}$ are presented.

The foam stability of powders stored at $\theta \leq 40^{\circ} \mathrm{C}$ did not differ significantly from Ref powders. On the other hand, foams made from the powders stored at $60^{\circ} \mathrm{C}$ were denser and those of $\mathrm{a}_{\mathrm{w}} 0.36$ were slightly more stable $(P>0.05)$ than Ref powders after $40 \mathrm{~min}$.

The coexistence of aggregated proteins and nonaggregated proteins has been assessed to be a key parameter for foaming properties (Foegeding et al., 2006). In accordance with our results, the latter study showed that an increase in the relative percentage of whey protein polymers in the solution led to more stable foams by decreasing the drainage rate with a concomitant decrease in the air phase volume. Nonaggregated proteins contributed to the foam formation as they dif- fuse to the interface faster, then unfold and adsorbed to form an aqueous film surrounding the air bubbles. These unfolded proteins at the interface can also serve as an anchor for aggregated proteins (Dimitrova et al.,

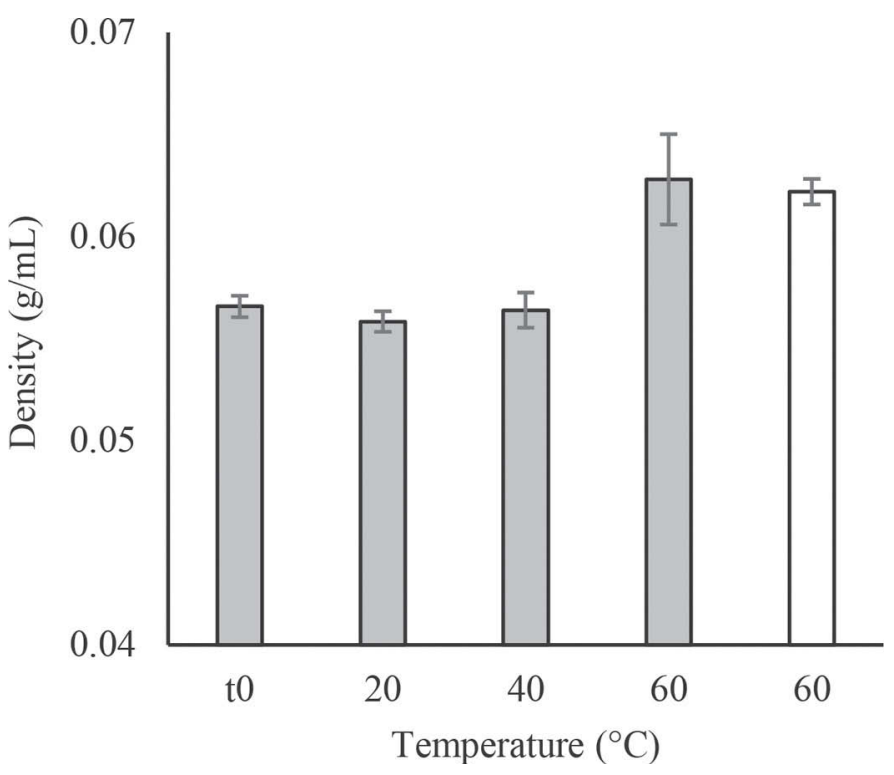

Figure 5. Effect of storage temperature on foam density. Powders of water activity $\left(\mathrm{a}_{\mathrm{w}}\right) 0.23$ at $t_{0}$ and stored for $12 \mathrm{mo}$ at 20 and $40^{\circ} \mathrm{C}$ and $6 \mathrm{mo}$ at $60^{\circ} \mathrm{C}$ (gray bar). Powder of $\mathrm{a}_{\mathrm{w}} 0.36$ stored for $6 \mathrm{mo}$ at $60^{\circ} \mathrm{C}$ (white bar). Standard deviation $<0.002 \mathrm{~g} / \mathrm{mL}$. 
2004). In our case, with more than $80 \%$ in the powder, the aggregates were likely to be forced to adsorption during foam threshing and participate in strengthening the viscoelasticity of the bubble interface. Moreover, these aggregated proteins contributed to the aqueous film stability by increasing its viscoelasticity and acting against the gravitational drainage and gas diffusion between bubbles (Zhu and Damodaran, 1994; Davis and Foegeding, 2004). Other authors have claimed that the increase in surface hydrophobicity could be considered as a decisive factor for the formation and stabilization of protein foams due to the rapid formation of viscoelastic films (Moro et al., 2011; Báez et al., 2013). The reverse-phase HPLC results showed a decrease in the amount of native protein with storage time in favor of more hydrophobic denatured proteins. These new hydrophobic particles could adsorb irreversibly and form a solid shell stabilizing bubbles against disproportion (Kam and Rossen, 1999) shown in a previous study.

Some of the aggregates that did not adsorb might provide additional stabilization mechanisms. They can become trapped in the film during foam formation and structure themselves into layers that are difficult to remove from the film (Sethumadhavan et al., 2001a,b). The foam stability is then improved by repulsive forces that structure the aqueous film (Sethumadhavan et al., 2001b). This kind of aggregate is also subjected to crosslinking between the interfaces to form a gel-like network that prevents the film from becoming thinner, therefore preventing the interfacial layers of air bubbles from becoming closer and finally helping to retain the solution in the film (Saint-Jalmes et al., 2005; Rullier et al., 2008). Moreover, these aggregates can be located in the plateau borders, playing a role of steric clutter impeding drainage.

It is assumed that shapes and sizes of aggregates are crucial to the stability of foams (Zhu and Damodaran, 1994; Fameau and Salonen, 2014; Rullier et al., 2010). However, the sizes of aggregates formed during storage in this study were heterogeneous and their shapes were not studied here to confirm this hypothesis.

\section{CONCLUSIONS}

The influence of representative storage conditions on structural changes that might explain the variability of functional properties of dairy powders during their application was studied. The results showed that WPI powders stored at temperatures below or equal to $20^{\circ} \mathrm{C}$ were relatively stable from both a structural and functional point of view up to 12 mo of storage. However, storage at $40^{\circ} \mathrm{C}$ induced significant changes in protein structure and browning of the WPI powders, although these structural changes did not necessarily result in changes in foaming properties. Indeed, a high level of stability of foaming properties was observed whatever the $a_{\mathrm{w}}$ of the powder and the storage duration at this temperature. At $60^{\circ} \mathrm{C}$, structural changes were rapid and pronounced, which affected foaming properties and slightly improved foam stability. According to the end use properties, such changes may constitute a defect or be desirable for the new functionalities they induce. Control of storage conditions is thus a critical step to ensure the final properties of WPI powders. Future applications for these results would be in the study of the effects of initial WPI composition on powder aging.

\section{ACKNOWLEDGMENTS}

The authors thank the CNIEL for their financial support and constructive exchange concerning the results. The authors also thank Julien Jardin [Science et Technologie du Lait et de l'Oeuf (STLO), Agrocampus Ouest, INRA, Rennes, France] for mass spectrometry experiments.

\section{REFERENCES}

Anema, S. G., D. N. Pinder, R. J. Hunter, and Y. Hemar. 2006. Effects of storage temperature on the solubility of milk protein concentrate (MPC85). Food Hydrocoll. 20:386-393. http://dx.doi. org/10.1016/j.foodhyd.2005.03.015.

Báez, G. D., P. A. Busti, R. Verdini, and N. J. Delorenzi. 2013. Glycation of heat-treated $\beta$-lactoglobulin: Effects on foaming properties. Food Res. Int. 54:902-909. http://dx.doi.org/10.1016/j. foodres.2013.08.013.

Burin, L., K. Jouppila, Y. Roos, J. Kansikas, and M. del P. Buera. 2000. Color formation in dehydrated modified whey powder systems as affected by compression and T(g). J. Agric. Food Chem. 48:5263-5268. http://dx.doi.org/10.1021/jf000240y.

Busti, P., C. A. Gatti, and N. J. Delorenzi. 2006. Binding of alkylsulfonate ligands to bovine $\beta$-lactoglobulin: Effects on protein thermal unfolding. Food Res. Int. 39:503-509. http://dx.doi.org/10.1016/j. foodres.2005.10.009.

Davis, J. P., and E. A. Foegeding. 2004. Foaming and interfacial properties of polymerized whey protein isolate. J. Food Sci. 69:C404C410.

Dimitrova, T. D., F. Leal-Calderon, T. D. Gurkov, and B. Campbell. 2004. Surface forces in model oil-in-water emulsions stabilized by proteins. Adv. Colloid Interface Sci. 108-109:73-86. http://dx.doi. org/10.1016/j.cis.2003.10.003.

Ellman, G. L. 1959. Tissue sulfhydryl groups. Arch. Biochem. Biophys. 82:70-77. http://dx.doi.org/10.1016/0003-9861(59)90090-6.

Fameau, A.-L., and A. Salonen. 2014. Effect of particles and aggregated structures on the foam stability and aging. C. R. Phys. 15:748-760. http://dx.doi.org/10.1016/j.crhy.2014.09.009.

Foegeding, E. A., P. J. Luck, and J. P. Davis. 2006. Factors determining the physical properties of protein foams. Food Hydrocoll. 20:284-292. http://dx.doi.org/10.1016/j.foodhyd.2005.03.014.

Gaiani, C., J. J. Ehrhardt, J. Scher, J. Hardy, S. Desobry, and S. Banon. 2006. Surface composition of dairy powders observed by X-ray photoelectron spectroscopy and effects on their rehydration properties. Colloids Surf. B Biointerfaces 49:71-78. http://dx.doi. org/10.1016/j.colsurfb.2006.02.015.

Gulzar, M., S. Bouhallab, J. Jardin, V. Briard-Bion, and T. Croguennec. 2013. Structural consequences of dry heating on alpha-lactalbumin and beta-lactoglobulin at pH 6.5. Food Res. Int. 51:899 906. http://dx.doi.org/10.1016/j.foodres.2013.02.025. 
Guyomarc'h, F., F. Warin, D. Donald Muir, and J. Leaver. 2000. Lactosylation of milk proteins during the manufacture and storage of skim milk powders. Int. Dairy J. 10:863-872.

Havea, P. 2006. Protein interactions in milk protein concentrate powders. Int. Dairy J. 16:415-422. http://dx.doi.org/10.1016/j. idairyj.2005.06.005.

Hoffmann, M. A. M., and P. J. J. M. van Mil. 1997. Heat-induced aggregation of $\beta$-lactoglobulin: Role of the free thiol group and disulfide bonds. J. Agric. Food Chem. 45:2942-2948. http://dx.doi. org/10.1021/jf960789q.

Howell, N. K., and C. Taylor. 1995. Effect of ascorbic acid on the foaming and gelling of globular proteins. Int. J. Food Sci. Technol. 30:321-334. http://dx.doi.org/10.1111/j.1365-2621.1995. tb01381.x.

Kam, S. I., and W. R. Rossen. 1999. Anomalous capillary pressure, stress, and stability of solids-coated bubbles. J. Colloid Interface Sci. 213:329-339. http://dx.doi.org/10.1006/jcis.1999.6107.

Le, T. T., J. W. Holland, B. Bhandari, P. F. Alewood, and H. C. Deeth 2013. Direct evidence for the role of Maillard reaction products in protein cross-linking in milk powder during storage. Int. Dairy J. 31:83-91. http://dx.doi.org/10.1016/j.idairyj.2013.02.013.

Leinberger, D. 2006. Temperature and humidity in ocean containers. Proceedings of Dimensions. International Safe Transit Association, East Lansing, MI.

Martin, A. H., K. Grolle, M. A. Bos, M. A. C. Stuart, and T. van Vliet. 2002. Network forming properties of various proteins adsorbed at the air/water interface in relation to foam stability. J. Colloid Interface Sci. 254:175-183. http://dx.doi.org/10.1006/ jcis.2002.8592.

Martinez-Alvarenga, M. S., E. Y. Martinez-Rodriguez, L. E. GarciaAmezquita, G. I. Olivas, P. B. Zamudio-Flores, C. H. AcostaMuniz, and D. R. Sepulveda. 2014. Effect of Maillard reaction conditions on the degree of glycation and functional properties of whey protein isolate-Maltodextrin conjugates. Food Hydrocoll. 38:110-118. http://dx.doi.org/10.1016/j.foodhyd.2013.11.006.

Maskan, M. 2001. Kinetics of colour change of kiwifruits during hot air and microwave drying. J. Food Eng. 48:169-175. http://dx.doi. org/10.1016/S0260-8774(00)00154-0.

McClements, D. J., F. J. Monahan, and J. E. Kinsella. 1993. Disulfide bond formation affects stability of whey protein isolate emulsions. J. Food Sci. 58:1036-1039. http://dx.doi. org/10.1111/j.1365-2621.1993.tb06106.x

Medrano, A., C. Abirached, L. Panizzolo, P. Moyna, and M. C. Añón. 2009. The effect of glycation on foam and structural properties of $\beta$-lactoglobulin. Food Chem. 113:127-133. http://dx.doi. org/10.1016/j.foodchem.2008.07.036.
Moro, A., G. D. Báez, P. A. Busti, G. A. Ballerini, and N. J. Delorenzi. 2011. Effects of heat-treated $\beta$-lactoglobulin and its aggregates on foaming properties. Food Hydrocoll. 25:1009-1015. http://dx.doi. org/10.1016/j.foodhyd.2010.09.021.

Norwood, E.-A., M. Chevallier, C. Le Floch-Fouéré, P. Schuck, R. Jeantet, and T. Croguennec. 2016. Heat-induced aggregation properties of whey proteins as affected by storage conditions of whey protein isolate powders. Food Bioprocess Technol. 1-9. http:// dx.doi.org/10.1007/s11947-016-1686-1. In press.

Roefs, S. P. F. M., and K. G. De Kruif. 1994. A model for the denaturation and aggregation of $\beta$-lactoglobulin. Eur. J. Biochem. 226:883-889. http://dx.doi.org/10.1111/j.1432-1033.1994.00883.x.

Rullier, B., M. A. V. Axelos, D. Langevin, and B. Novales. 2010. $\beta$-Lactoglobulin aggregates in foam films: Effect of the concentration and size of the protein aggregates. J. Colloid Interface Sci. 343:330-337. http://dx.doi.org/10.1016/j.jcis.2009.11.015.

Rullier, B., B. Novales, and M. A. V. Axelos. 2008. Effect of protein aggregates on foaming properties of $\beta$-lactoglobulin. Colloids Surf. Physicochem. Eng. Asp. 330:96-102. http://dx.doi.org/10.1016/j. colsurfa.2008.07.040.

Saint-Jalmes, A., M.-L. Peugeot, H. Ferraz, and D. Langevin. 2005. Differences between protein and surfactant foams: Microscopic properties, stability and coarsening. Colloids Surf. Physicochem. Eng. Asp. 263:219-225. http://dx.doi.org/10.1016/j. colsurfa.2005.02.002

Sawyer, L., G. Kontopidis, and S.-Y. Wu. 1999. $\beta$-Lactoglobulin-A three-dimensional perspective. Int. J. Food Sci. Technol. 34:409 418.

Sethumadhavan, G. N., A. D. Nikolov, and D. Wasan. 2001a. Film stratification in the presence of colloidal particles. Langmuir 17:2059-2062. http://dx.doi.org/10.1021/la0009361.

Sethumadhavan, G. N., A. D. Nikolov, and D. T. Wasan. 2001b. Stability of liquid films containing monodisperse colloidal particles. J. Colloid Interface Sci. 240:105-112. http://dx.doi.org/10.1006/ jcis.2001.7628.

Stapelfeldt, H., B. R. Nielsen, and L. H. Skibsted. 1997. Effect of heat treatment, water activity and storage temperature on the oxidative stability of whole milk powder. Int. Dairy J. 7:331-339.

Visschers, R. W., and H. H. J. de Jongh. 2005. Disulphide bond formation in food protein aggregation and gelation. Biotechnol. Adv. 23:75-80. http://dx.doi.org/10.1016/j.biotechadv.2004.09.005.

Zhu, H., and S. Damodaran. 1994. Heat-induced conformational changes in whey protein isolate and its relation to foaming properties. J. Agric. Food Chem. 42:846-855. http://dx.doi.org/10.1021/ jf00040a002 